\title{
Indonesia paleotsunami database as an effort to reduce the tsunami disasters in Indonesia
}

\author{
Ihda Ibtihaj ${ }^{1}$, Supriyanto Suparno ${ }^{2 *}$, Muhammad Rizqy Septyandy ${ }^{1}$, Gamma Abdul Jabbar ${ }^{1}$, Tri Rani Puji Astuti ${ }^{1}$ \\ ${ }^{1}$ Geology Study Program, University of Indonesia, Pondok Cina, Beji, Depok, 16424, Indonesia \\ ${ }^{2}$ Geophysics Study Program, University of Indonesia, Pondok Cina, Beji, Depok, 16424, Indonesia
}

\begin{abstract}
Indonesia's tectonic activity is one of the most active in the world. These conditions make Indonesia prone to earthquakes, tsunamis, and volcanic eruptions. Tsunamis are large ocean waves that are formed through several processes such as underwater earthquakes, underwater landslides, volcanic activity, and asteroid impacts. Indonesia has been hit by various tsunami events. However, not all characteristic tsunami events are well known and recorded. Knowing the characteristics of a tsunami occurrence is very important to understand the frequency and intensity of tsunamis in the present. This research create a WebGIS database for paleotsunami in Indonesia. Tsunami incident data comes from literature related to tsunami events such as books, journals, reports, final projects, and others. Making WebGIS in this study will be developed using website programming, namely HTML, CSS, and JavaScript. The research results obtained 302 tsunami data. The period of tsunami in this research is from Late Miocene to the last tsunami in 2018. The WebGIS created presents a database of tsunami events in Indonesia, a dashboard of Indonesian tsunami statistics, and a tsunami learning educational feature. It is hoped that the results of this database will serve as a means of information for future paleotsunami research needs and as a means of education regarding the potential for tsunamis in Indonesia.
\end{abstract}

\section{Introduction}

Indonesia is a country located at the confluence of four major plates, namely Eurasia, Indo-Australia, the Philippines, and the Pacific [1]. Complex plate tectonic conditions make Indonesia one of the regions in the world with the most active tectonic activity [2]. As a result of these conditions, Indonesia is prone to earthquakes, tsunamis, and volcanic eruptions.

Tsunamis are the most powerful ocean wave motions. The mechanism for the formation of a tsunami is through processes that produce shock waves, such as underwater earthquakes, underwater landslides, volcanic activity, and asteroid impacts [3]. The occurrence of a tsunami is a disaster because it has caused damage, loss of life, and property loss as well as damage to ecosystems [4].

When a tsunami occurs, the waves will carry material from the deep seafloor in the form of clay. When approaching the coast, the tsunami also erodes the beach base, which generally consists of sand. So there is a mixture of beach sand material and deep sea mud. The larger the tsunami that occurs, the tsunami inundation zone (inundation) and the material it carries will spread farther inland. After the tsunami energy weakens, the seawater returns to the sea (backwash) at a slower speed so that the sand material carried does not come back but is deposited on land. Deposition brought by the tsunami will cover the coastal plain and the existing soil or vegetation [5].

Tsunami deposits are deposits carried by the tsunami, which are left on the coast during the inundation phase or returned to the sea during the backwash phase. These deposits are used to identify past tsunami events (paleotsunami) [5]. Paleotsunami is a tsunami that occurs before historical records or there are no written observations [6]. Paleotsunami deposits can be identified using paleotsunami proxies.

The potential for a tsunami disaster is very likely to occur in Indonesia. At least there have been various series of tsunami events that have caused many casualties, both caused by underwater earthquakes and underwater volcanic eruptions. However, in most of the tsunami events that have hit Indonesia, the mechanism and character of the tsunami are not well known [2]. Historical information and data on tsunami events in an area can be used as a reference for understanding the frequency and intensity of tsunami disasters in the present $[5,7]$. Therefore, it is necessary to create a historical database of tsunami events in Indonesia as an effort to reduce tsunami risk.

Indonesia Paleotsunami Database will be made based on WebGIS. WebGIS is a Geographic Information System (GIS) that uses the internet network as the main access to distribute spatial data and information as well as GIS analysis [8]. The use of WebGIS was chosen because this method can be easily

\footnotetext{
* Corresponding author: supriyanto@sci.ui.ac.id
} 
accessed by the general public. The results of this database is expected to be a means of information for future paleotsunami research needs as well as a means of education regarding the potential for tsunamis in Indonesia.

\section{Methods}

\subsection{Paleotsunami proxy}

Paleotsunami proxies are various criteria used to identify deposits caused by tsunami processes [9]. The use of proxies in paleotsunami research has not become a standard thing and is still being developed today. The most common paleotsunami proxy and has been widely used in paleotsunami research is the proxy developed by Goff et al. (2011) [10]. Paleotsunami proxy presented in Table 1.

Table 1. Paleotsunami Proxy

\begin{tabular}{|c|c|}
\hline $\begin{array}{l}\text { Proxy } \\
\text { Number }\end{array}$ & Proxy \\
\hline 1 & Grain size \\
\hline 2 & Fining upwards sediment \\
\hline 3 & $\begin{array}{l}\text { Sediment units that differ/contrast with other } \\
\text { layers. }\end{array}$ \\
\hline 4 & $\begin{array}{l}\text { sub-units that characterize tsunami runup } \\
\text { and backwash. }\end{array}$ \\
\hline 5 & Contact unconformity or erosional. \\
\hline 6 & Contains a rip-up clast of reworked material. \\
\hline 7 & $\begin{array}{l}\text { The loading structure at the bottom of the } \\
\text { deposit }\end{array}$ \\
\hline 8 & $\begin{array}{l}\text { Microscale features may be visible on thin } \\
\text { sections }\end{array}$ \\
\hline 9 & $\begin{array}{l}\text { Measurement of anisotropy magnetic } \\
\text { susceptibility (AMS) combined with grain } \\
\text { size analysis. }\end{array}$ \\
\hline 10 & Heavy mineral laminates \\
\hline 11 & $\begin{array}{l}\text { Increased concentration of elements sodium, } \\
\text { sulfur, chlorine, calcium, strontium, } \\
\text { magnesium, titanium, zirconium }\end{array}$ \\
\hline 12 & $\begin{array}{l}\text { Possible contamination by heavy metals and } \\
\text { metalloids }\end{array}$ \\
\hline 13 & Geochemical evidence \\
\hline 14 & $\begin{array}{l}\text { Shells of marine organisms and rich layers } \\
\text { of shells. }\end{array}$ \\
\hline 15 & $\begin{array}{l}\text { Crushed shells, wood, and various other } \\
\text { materials are often found "inserted" in the } \\
\text { layers of deposits. }\end{array}$ \\
\hline 16 & $\begin{array}{l}\text { It may be associated with vascular plant } \\
\text { remains, paleosoil, or buried bone remains. }\end{array}$ \\
\hline 17 & $\begin{array}{l}\text { Associated with an increase of diatoms } \\
\text { living in marine environments - brackish } \\
\text { water }\end{array}$ \\
\hline 18 & $\begin{array}{l}\text { Found a collection of foraminifera shells (or } \\
\text { other fossils }\end{array}$ \\
\hline 19 & $\begin{array}{l}\text { Terrestrial pollen concentrations decrease on } \\
\text { and/or coastal pollen concentrations } \\
\text { increase. }\end{array}$ \\
\hline 20 & $\begin{array}{l}\text { The existence of archaeological sites that are } \\
\text { overlaid or overlain by layers of sediment. }\end{array}$ \\
\hline 21 & $\begin{array}{l}\text { There is a collection of archaeological } \\
\text { middens }\end{array}$ \\
\hline
\end{tabular}

\begin{tabular}{|c|l|}
\hline 22 & $\begin{array}{l}\text { Archaeological sites (buildings) that have } \\
\text { been damaged by water waves. }\end{array}$ \\
\hline 23 & $\begin{array}{l}\text { Archaeological sites that have been re- } \\
\text { deposited in inappropriate locations. }\end{array}$ \\
\hline 24 & $\begin{array}{l}\text { Replication, layers of coastal archaeological } \\
\text { remain and piles of shells }\end{array}$ \\
\hline 25 & Local folklore about the tsunami. \\
\hline 26 & Paleogeomorphological acquisitions. \\
\hline 27 & $\begin{array}{l}\text { Paleogeomorphology at the time of } \\
\text { inundation }\end{array}$ \\
\hline 28 & Local or regional tsunamigenic knowledge. \\
\hline 29 & $\begin{array}{l}\text { Local and regional knowledge of ancient } \\
\text { environments }\end{array}$ \\
\hline 30 & $\begin{array}{l}\text { Similar coastal deposits were found } \\
\text { regionally indicating regional inundation. }\end{array}$ \\
\hline
\end{tabular}

\subsection{Data collection and processes}

The data used in this research include scientific journals, papers, research reports, final projects, or other publications related to the history of the tsunami incident in Indonesia. Data collected on tsunami events in Indonesia can come from valid geoscience, archeological or folklore perspective. Tsunami event data that has been collected then matriculated. Data matriculation processing uses Microsoft Excel 2016.

The data resulting from the matriculation will then be processed into GeoJSON data (Geospatial JavaScript Object Notation). Data tsunami GeoJSON will be data in the form of a point (point) indicated that at the location of the point is never the tsunami. In addition, this data contains important information about the occurrence of a tsunami at that location.

Making WebGIS in this research developed using website programming. The programs used are HTML (Hypertext Markup Language), CSS (Cascading Style Sheets), and JavaScript. WebGIS present important information content related to paleotsunami in Indonesia. The attributes used to present content in WebGIS presented in table 2.

Table 2. Database Attributes

\begin{tabular}{|c|c|}
\hline No & Attributes \\
\hline 1 & Province / Regional Location \\
\hline 2 & Location of the tsunami incident \\
\hline 3 & $\begin{array}{l}\text { The latitude and longitude of the } \\
\text { tsunami/paleotsunami point }\end{array}$ \\
\hline 4 & $\begin{array}{l}\text { Location status (there is an unknown deposit or } \\
\text { deposit) }\end{array}$ \\
\hline 5 & $\begin{array}{l}\text { Physical characteristics (tsunami candidate } \\
\text { deposition conditions, or other enabling } \\
\text { conditions) }\end{array}$ \\
\hline 6 & $\begin{array}{l}\text { Classification of the time of occurrence } \\
\text { • } \quad \text { Historical (1800 AD - present) } \\
\text { • } \quad \text { Prehistorical (years <1800 AD) }\end{array}$ \\
\hline 7 & Time of occurrence \\
\hline 8 & $\begin{array}{cl}\text { Validity } & \\
\text { - } & \text { Fair (1-4 criteria of proxy) } \\
\text { - } & \text { Moderate (5-8 criteria of proxy) } \\
\text { - } & \text { Excellent ( }>9 \text { criteria of proxy) }\end{array}$ \\
\hline 9 & Nature of evidence \\
\hline 10 & Description of nature of evidence \\
\hline
\end{tabular}




\begin{tabular}{|l|l|}
\hline 11 & Dating Technique \\
\hline 12 & Dating Method \\
\hline 13 & Paleotsunami point elevation \\
\hline 14 & Inundation zone boundaries \\
\hline 15 & The thickness of the sediment/sediment formed \\
\hline 16 & The cause of the tsunami \\
\hline 17 & Tsunami source location and coordinates \\
\hline 18 & Paleotsunami proxy used \\
\hline 19 & Reference \\
\hline
\end{tabular}

\subsection{Data analysis}

The analysis conducted in this research is quantitative analysis. The mechanism that caused the tsunami that hit Indonesia was recorded with the frequency of occurrence. Paleotsunami proxies used for identification are also recorded in frequency of use in paleotsunami identification studies in Indonesia. The results of the analysis become data on the frequency of mechanisms that cause tsunami events in Indonesia and the frequency of paleotsunami proxies that are widely used in Indonesia.

\section{Results and discussion}

\subsection{Database processing results}

The tsunami incident data that was collected and entered into the database amounted to 302 data. Based on this research database tsunami period which is have been collected, oldest recorded tsunami events are paleotsunami deposits thought to be Late Miocene based on the foraminifera fossils contained [5]. Meanwhile, the most recent incident was the tsunami in 2018 which hit Lombok, West Nusa Tenggara and Palu, Central Sulawesi [12]. Data from the literature that is entered into the matriculation is information according to the required attributes. The results of the database matriculation are presented in Figure 1.

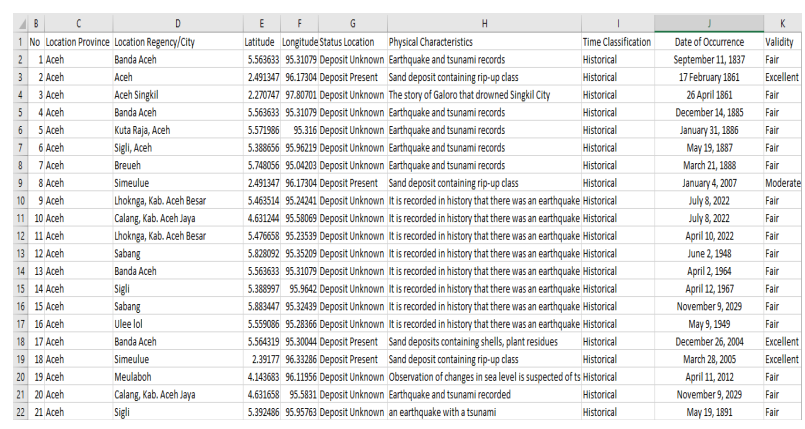

Fig. 1. Database matriculation

The distribution of tsunami data in Indonesia, almost all of Indonesia's coasts have been hit by a tsunami. The West Coast of Sumatra Island is the area that has experienced the most tsunamis. The southern regions of Java, North Sulawesi and the Maluku Islands have also experienced many tsunamis. The East Coast of Kalimantan Island is the area least affected by the tsunami. This shows that almost all regions in Indonesia have the potential for a significant tsunami disaster.

\subsection{Causes of the tsunami in Indonesia}

The mechanism that caused the tsunami in Indonesia has been grouped to determine the dominant cause. The results of data grouping show that the causes of tsunamis in Indonesia have several mechanisms, namely earthquakes, volcanism, landslides and combined mechanisms. the recapitulation of the causes of the tsunami in Indonesia is presented in Figure 2.

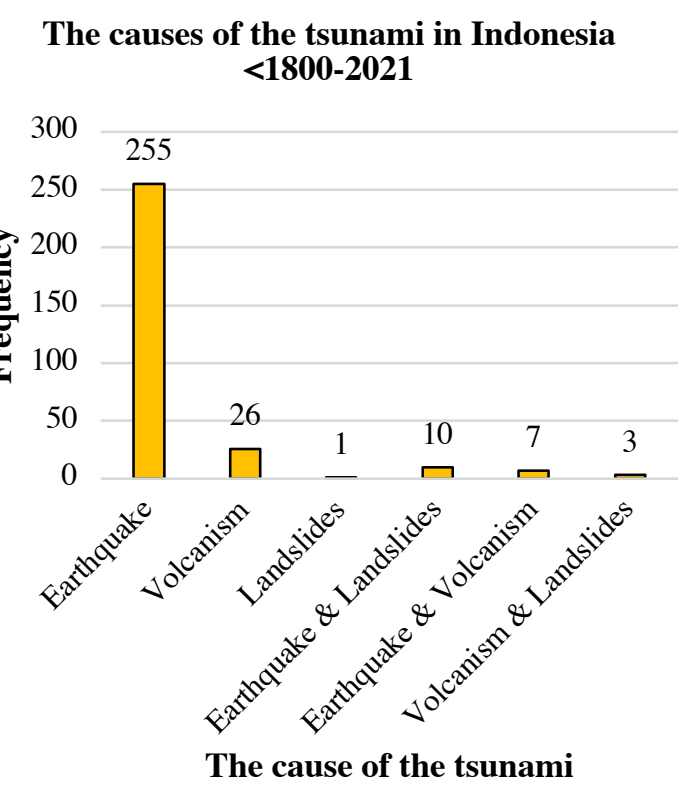

Fig. 2. Chart of the causes of the tsunami in Indonesia

Earthquakes are the mechanism that causes most tsunamis in Indonesia. Based on the database, the occurrence of tsunamis caused by earthquakes mostly occurs in areas associated with the location of active faults. Several active fault zones that are the source of earthquakes that cause tsunamis include the Sunda Megathrust, Banda Megathrust, Flores Rise Fault, North Sulawesi Megathrust, Papua Megathrust, Sangihe Megathrust, and local faults [11, 12].

Coastal areas adjacent to the presence of active faults and subduction zones are areas that have the most potential for tsunamis caused by earthquakes. This is because the area has high seismic activity. So, it causes a lot of earthquakes [2]. Based on the database for the western region of Sumatra, southern Java, the Banda arc, and the Maluku Sea, these are the dominant areas where earthquakes trigger tsunamis. The area is a subduction zone with high seismic activity that causes many earthquakes.

Volcanism activities that occur in Indonesia have been the cause of the tsunami. The eruption of Mount Krakatau on August 26, 1883, was a volcanic activity that caused tsunami waves that impacted Lampung and Banten [13, 14, 15, 16]. The Lampung and Banten regions were also affected by the tsunami on December 22,2018, due to volcanism from Mount Anak Krakatau. 
Volcanic activity from Mount Krakatau and Anak Krakatau is one of the pieces of evidences from the past and present that volcanism has the potential to cause tsunamis.

Underwater avalanches are the mechanism that once caused a tsunami in Indonesia. Tsunamis caused by submarine avalanches are rare according to the database. Although rare, tsunamis caused by avalanches are also a risk of disaster.

\subsection{Paleotsunami proxy applied in Indonesia}

The Indonesian paleotsunami proxy in this study is a collection of proxies grouped based on the created database. The grouping of proxies is done to find out which proxies are dominant and effectively used in Indonesia. The most widely used proxy is proxy number 28 while the least used is proxy number 23 (figure 3 ). Based on the grouping of proxy data from the literature used by paleotsunami research in Indonesia, only 28 of the 30 proxies are available. Proxies number 24 and 27 have not been implemented in Indonesia.

Proxy number 28 is the most widely used proxy. This is because the tsunami data was identified dominantly using contextual data. The contextual data used are such as tsunami catalogs or historical records. The use of contextual data as a proxy shows that paleotsunami research in Indonesia needs further development. The application of other proxies that identify field data needs to be developed so that concrete evidence of a tsunami can be found in deposits in the field.

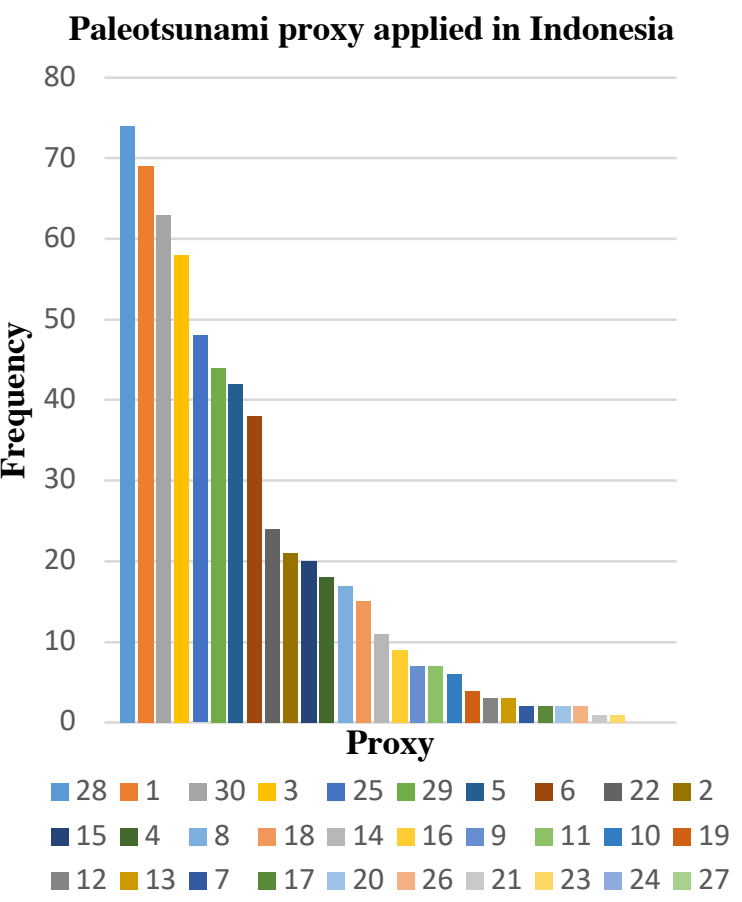

Fig. 3. Chart of paleotsunami proxy applied in Indonesia

Proxy number 24 is the identification of coastal archeological replication and shells due to inundation.
Based on the database, paleotsunami research in Indonesia has not done too much identification of paleotsunami with archaeological data. One of the paleotsunami studies that identified paleotsunami deposits with archaeological evidence was the research conducted by Daly et al. (2019) [17]. The research carried out was to identify the presence of ceramic shards on the North Coast of Aceh which indicated its presence on the coast due to the tsunami process. Collaboration of geological data with archaeological data needs to be developed in paleotsunami research. This is done so that proxy number 24 can be applied in Indonesia.

Proxy number 27 is the identification of paleotsunami based on paleogeomorphology when the inundation condition was not due to a storm but a tsunami. When the tsunami waves come to the mainland, the waves hit the coastal morphology so that there are morphological changes [18]. These morphological changes were identified to indicate a tsunami. The application of this proxy requires special research in the form of coastal paleogeomorphological research to reconstruct the morphological condition of the coast which is then correlated with the presence of sediment. Paleotsunami research that applies paleogeomorphological analysis in Indonesia is still minimal, so that proxy number 27 has not been used. The research related to tsunamis and morphological changes was carried out by Maramai \& Tinti (1997) after the 1994 Banyuwangi tsunami [18]. However, the 1994 Banyuwangi tsunami was a tsunami that occurred in the present and was recorded. So, the development of paleogeomorphological proxies needs to be done to be applied in Indonesia. This development will have a positive impact because evidence of paleotsunami can increase and the quality of the data will improve.

\subsection{Validity of Indonesian tsunami data}

The validity of the data in this study was determined based on the number of proxies used in identifying tsunami events. Validity is Excellent if the number of proxies applied for the identification of tsunami events is 9 proxies. Validity is Moderate if the number of proxies applied for the identification of tsunami events is 5-8 proxies. Validity is Fair if the number of proxies applied for tsunami event identification is 1-4 proxies [19]. The results show that the validity of the tsunami incident data in Indonesia is in three categories, namely Excellent, Moderate and Fair. The number of data validity is Excellent as many as 19, Moderate as many as 53 and Enough as much as 230 (figure 4). The validity of this data reflects the quality of tsunami event data based on a large amount of literature and proxies used to identify tsunami events. The more literature and proxies used, the better the validity of the data. The amount of literature but the proxies used are the same and do not make the number of proxies used increase, so the validity of the data does not increase.

Excellent data validity can be said as accurate tsunami event information. Accurate in this study is the 
characteristics of the tsunami event can be known in detail. This detailed information can be used as a reference for further study for further research on the occurrence of tsunamis. Moderate data validity means that the information presented regarding the characteristics of the tsunami is quite good but not as detailed as the excellent validity. Data that has fair validity does not mean that the data is wrong, but the lack of literature that explains in detail the characteristics of the tsunami occurrence and deposition.

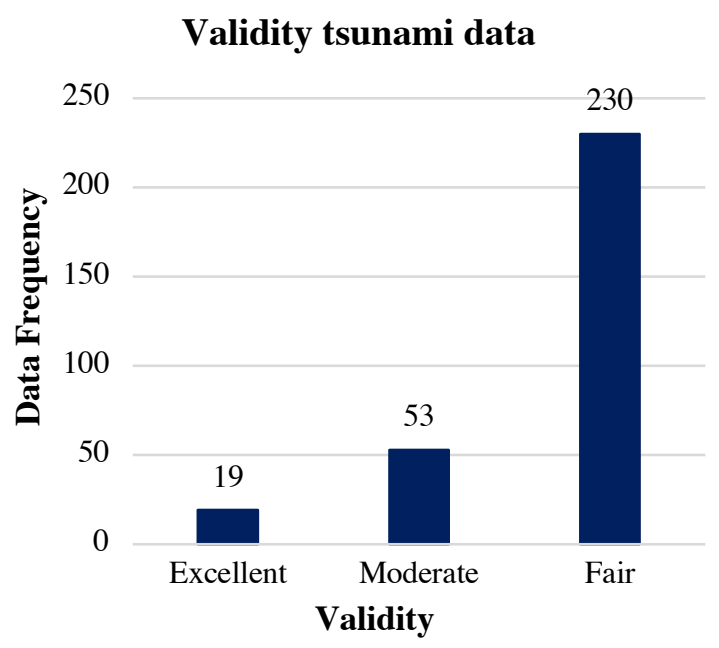

Fig. 4. Chart of the validity tsunami data in Indonesia

Most of the tsunami events in Indonesia have fair data validity. Tsunamis that occur in historical and prehistorical periods are both classified as fair validity. The validity of this fair data is due to the lack of literature that records in detail the tsunami incident. The lack of literature can be due to several reasons, such as the lack of infrastructure that records and reports tsunami events, research on paleotsunami deposits is still limited, the lack of previous community knowledge about tsunamis so that there are no records or just local folklore that lacks detail explaining the tsunami incident.

Improving the validity of tsunami event data in Indonesia can be done by developing paleotsunami research. Paleotsunami research can strengthen data on already recorded tsunami events or find evidence of new paleotsunami events. The development of paleotsunami research can increase the number of proxies used to identify tsunami events in Indonesia so that the validity of the data can be better.

\subsection{Geological paleotsunami proxy}

Geological proxies are criteria for the identification of suspected paleotsunami deposits based on geological aspects [10]. Geological proxies are the best proxies for identifying tsunami events. When a tsunami occurs, the tsunami waves will carry material from the sea and form sediment on land. The sedimentation results from tsunami waves will become tsunami deposits or known as tsunamiites [4]. A well-preserved tsunami deposit will be strong evidence that a tsunami has occurred, both for identification now and in the future. The presence of tsunami deposits will make geological proxies workable.

The use of geological proxies will make it easier to identify deposits caused by tsunamis because tsunami deposits have distinctive sediment characteristics. The quality of data that uses geological proxies is better than other data that does not apply geological proxies. Based on the database, tsunami events identified by geological proxies have Moderate - Excellent data validity.

Geological proxies that are widely used in paleotsunami research in Indonesia are proxy number 1, namely grain size, and proxy number 3 , namely the presence of contrast layers. This proxy is widely used because the identification of grain size is quite easy to do, and the grain size will be correlated with the contrast layer. Differences in grain size in a stratigraphic crosssection of sediment samples for paleotsunami identification will be seen macroscopically, then layers that contrast with the general layer can also be seen macroscopically using this criterion the suspected paleotsunami layer can be identified. Most of the paleotsunami research in Indonesia based on the database has implemented the 1 st and 3rd proxies and is supported by other proxies.

However, not all tsunami events in Indonesia have been identified with geological proxies. This is due to the lack of research related to paleotsunami deposits in more detail in several regions in Indonesia. Information related to tsunami events is still based on historical records or anthropological evidence. In the future, the development of geological proxies is needed to identify paleotsunami deposits. The development of paleotsunami research using geological proxies in Indonesia can improve data quality and validity in the database for the better.

\subsection{WebGIS Indonesia paleotsunami database}

The WebGIS created in this research is a website-based map (WebMap) database of tsunami events in Indonesia. The information presented is data on tsunami events in Indonesia and their characteristics. All information in this WebGIS is free to access at no cost and the data in this WebGIS is open source. The widgets presented in WebGIS are the basic menus in WebGIS. The main features of this WebGIS are layer selection, attribute detail information, and data download. As for this WebGIS will be included supporting features to make the data presented more informative and easily accessible. WebGIS Indonesia Tsunami Event Database can be accessed via the link https://trc-ui.geosinyal.id/

\subsubsection{WebGIS view}

The initial view of the WebGIS Indonesia Paleotsunami Database will display a Map of Indonesia and data on tsunami events in Indonesia marked with a blue wave symbol. The design of this WebGIS display is made 
informative and attractive so that the general public can easily access and understand the information in WebGIS. In general, the basic appearance of WebGIS consists of a menu bar at the top and a widget (figure 5).

The menu bar contains information about WebGIS. In the menu bar you can get information about WebGIS such as about, disclaimer, map legend, download dashboard feature data and tsunami study feature. The data presented in WebGIS is open source, including the overall tsunami incident data, proxies used and reference sources.

Widgets in WebGIS are basic features in a Webbased Geographic Information System (figure 6). These widgets include a layer widget to set the data layer that is cool to display. Then, the widget zooms in and out to zoom in and out on the map. Then, a search widget to search for a specific location, a home widget to return to the home screen, and a my location widget to find out where the user is.

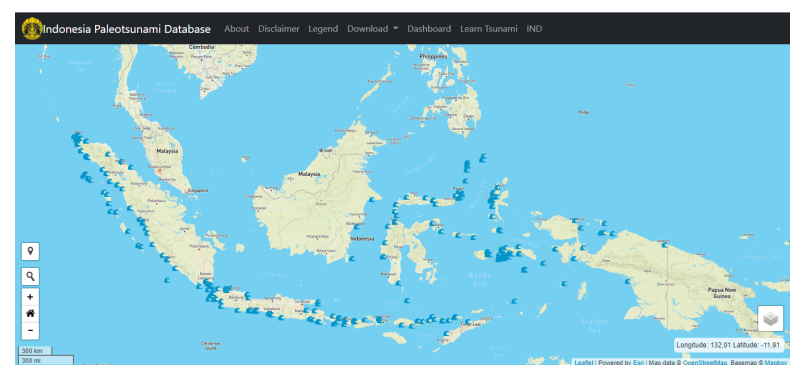

Fig. 5. User interface WebGIS view

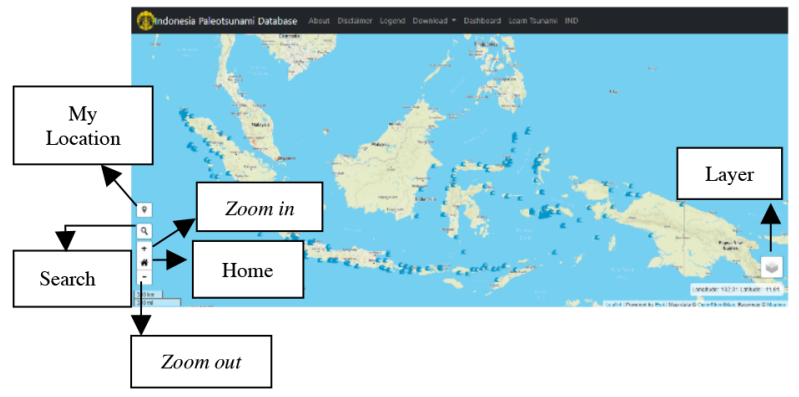

Fig. 6. Widget on WebGIS

\subsubsection{WebGIS layers}

Layer in WebGIS is divided into 2, namely the main layer and additional layers. The main layer is the main data for tsunami events including the "All Data", "Classification", "Validity", "Nature of Evidence", "Deposit Status", and "Tsunami Cause" layers. Meanwhile, the additional layer is a layer that contains supporting data including the "Source Tsunami", "Fault" layer, "Subduction" layer, and " Indonesia's Volcano" layer. The data presented can be selected based on the available layers. The map will only display data according to the layer that is activated. The display of the layer settings that you want to display is presented in figure 7 .

\subsubsection{Features detailed Information characteristics of Tsunami}

The detailed information feature of tsunami characteristics is a feature of quick access to the attributes of the tsunami database. This feature can be accessed by clicking on the symbol of the desired tsunami event to know in more detail its characteristics. Detailed information will appear after the symbol is clicked. Information will be presented in the form of a pop-up dialog box containing the attributes of the selected tsunami event. The pop-up dialog box display is shown in figure 8 .

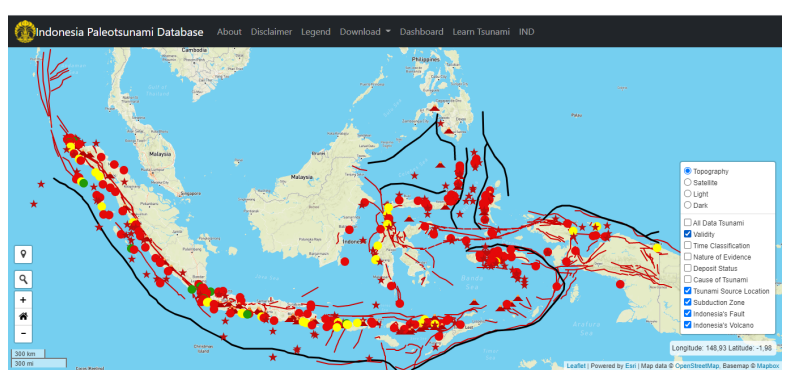

Fig. 7. Layers available in WebGIS

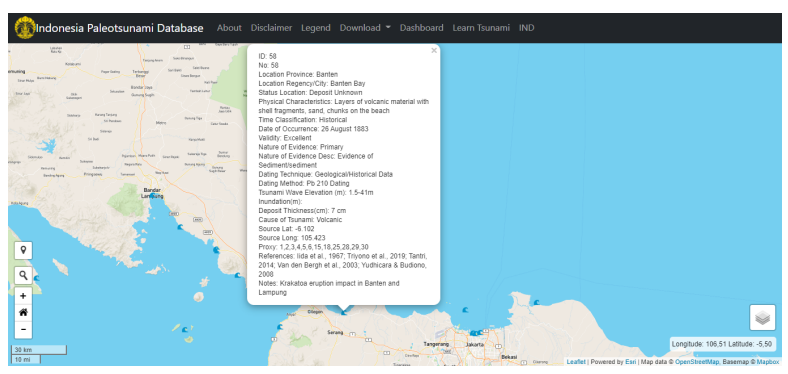

Fig. 8. The pop-up box displays the tsunami event attributes

\subsubsection{Indonesia paleotsunami database dashboard}

The Indonesian Tsunami Database Dashboard is a supporting facility in WebGIS. The dashboard provides statistical infographics and tables of tsunami events in Indonesia (figure 9). The infographic on the dashboard displays statistical data from the data layer in WebGIS. The tsunami occurrence table displays tsunami data along with the characteristics of tsunamis that have occurred in Indonesia. This facility can be accessed by clicking the "Dashboard" menu in the WebGIS menu bar.

\subsubsection{Learn tsunami features on WebGIS}

The tsunami study feature is a supporting feature in WebGIS. The feature can be accessed by clicking the "Learn Tsunami" menu on the menu bar in WebGIS. This feature provides educational information about tsunamis. The educational information presented is in the form of articles on a website view that can be read by the accessor (figure 10). The education delivered was about tsunamis, tsunami mechanisms, paleotsunami, 
and paleotsunami proxies. The existence of this feature is a supporting tool for educating the general public who access WebGIS to better understand the data presented in WebGIS and increase their knowledge about tsunamis.

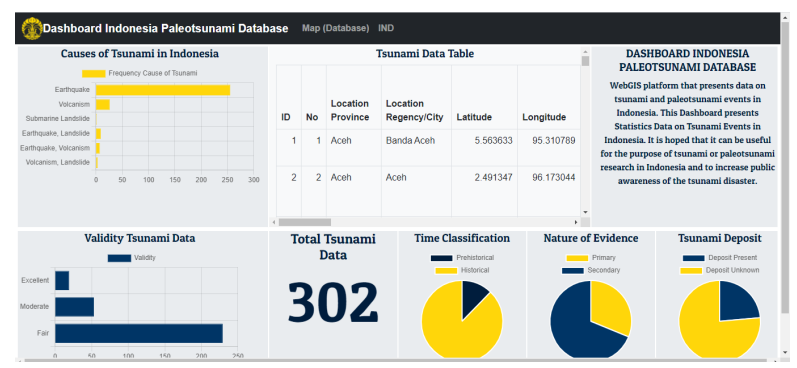

Fig. 9. The display of Indonesia Paleotsunami Database Dashboard

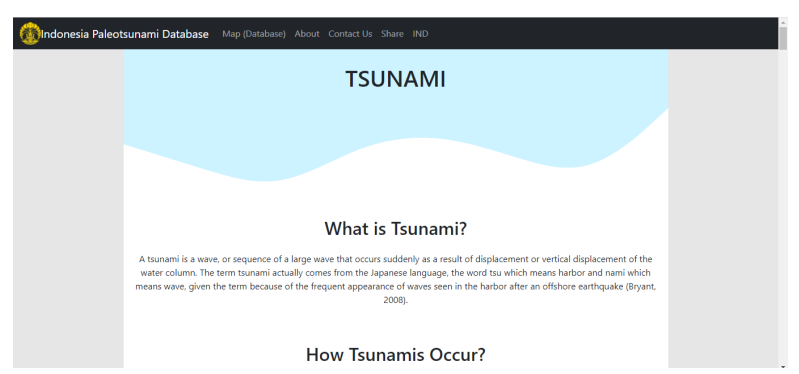

Fig. 10. The display of the learn tsunami feature

\section{Conclusion}

Data on tsunami events entered into the database amounted to 302 data. Tsunami events in Indonesia were caused by 255 earthquakes, 26 volcanism, 1 landslide, 10 earthquakes - landslides, 7 earthquakes volcanism, and 3 volcanism - landslides. There are 28 proxies used to identify tsunami events in Indonesia out of 30 available proxies. Proxy number 28 is the dominant proxy used. The application of geological proxies can improve data quality. The validity of the tsunami data in Indonesia was "Excellent" as many as 19, "Moderate" as 53, and "Fair" as 230. WebGIS Indonesia Tsunami Event Database can be accessed via the link https://trc-ui.geosinyal.id/. Information that can be accessed in WebGIS is the database of tsunami events and paleotsunami deposits in Indonesia, the Indonesian tsunami statistical data dashboard, and the educational feature for studying tsunamis. The database in this research will continue to be updated in line with the development of tsunami research in Indonesia

Acknowledgment. The authors would like to thank Program Study Geology and Geophysics Universitas Indonesia for Supporting this research. The authors also would like to thank The Ministry of Research and Technology for providing the Basic Research for Higher Education Grant to fund this research.

\section{References}

1. P.C. Nugroho, S.E. Pinuji, A.N. Ichwana, A. Nugraha, S. Wiguna, et al, IRBI (Indeks Resiko Bencana Indonesia) Tahun 2018, BNPB, (2018)

2. H. Latief, N.T. Puspito, F. Immamura, Tsunami Catalog and Zones in Indonesia. J. Nat. Disaster Sci., 22, 25-43 (2000)

3. E. Bryant, Tsunami The Underrated Hazard, Springer, (2008)

4. T. Shiki, Y. Tsuji, K. Minoura, T. Yamazaki, Tsunamiites - Features and Implications, Elsevier, (2008)

5. Y.Zaim, Daryono, I.N. Sukanta, Y. Rizal, Aswan, R.O. Wahyu, et al., Jejak Tsunami Masa Lalu diantara Pangandaran dan Cilacap. Earthquake and Tsunami Center Deputy for Geophysics, (2018)

6. Intergovernmental Oceanographic Commission, Tsunami Glosary, UNESCO, (2019)

7. P. Dunbar, H. McCullough, Global tsunami deposits database, J. Nat. Hazards, 63, 267-278 (2012)

8. R. Abdalla, M. Esmail, WebGIS for Disaster Management and Emergency Response, Springer, (2019)

9. Chagué-Goff, C., Schneider, J. L., Goff, J. R., Dominey-Howes, D., \& Strotz, L. (2011). Expanding the proxy toolkit to help identify past events - Lessons from the 2004 Indian Ocean Tsunami and the 2009 South Pacific Tsunami. Earth-Science Rev. (2011)

10. J. Goff, C. Chagué-Goff, S. Nichol, B. Jaffe, D. Dominey-Howes, Progress in palaeotsunami research, Sediment. Geol., 243-244, 70-88 (2011)

11. R. Harris, J. Major, Waves of destruction in the East Indies: The Wichmann catalogue of earthquakes and tsunami in the Indonesian region from 1538 to 1877 , Geol. Soc. Spec. Publ., 441, 946 (2016)

12. R. Triyono, T. Prasetya, S. D. Anugrah, A. Sudrajat, U. Setiyono, et al., Katalog Tsunami Indonesia Per-Wilayah Tahun 416-2018, BMKG, (2019)

13. K. Iida, D. C. Cox, G. Pararas-Carayannis, Preliminary catalog of tsunamis occurring in the Pacific Ocean, Hawaii Inst. of Geophys., (1967)

14. B.W. Mutaqin, F. Lavigne, D.S. Hadmoko, M.N. Ngalawani, Volcanic Eruption-Induced Tsunami in Indonesia: A Review, IOP Conf. Ser. Earth and Environ. Sci., 256 (2019)

15. P. S. Putra, E. Yulianto, Stratigrafi Endapan tsunami Krakatau 1883 di Daerah Limus, Pantai Barat Teluk Semangko, Lampung. J. Lingkungan Dan Bencana Geol., 7 (2016)

16. P. S. Putra, E. Yulianto, Karakteristik Endapan Tsunami Krakatau 1883 Di Daerah Tarahan, Lampung. J. RIS. Geol. dan Pertam., 27 (2017)

17. P. Daly, K. Sieh, T.Y. Seng, E.E. McKinnon, A.C. Parnell et al., Archaeological evidence that a late 14th-century tsunami devastated the coast of northern Sumatra and redirected history, in 
Proceedings of the National Academy of Sciences, May 2019, America (2019)

18. A. Maramai, S. Tinti, The 3 June 1994 Java Tsunami: A post-event survey of the coastal effects, J. Nat.l Hazards, 15, 31-49 (1997)

19. J. Goff, S. Nichol, D. Kennedy, Development of a palaeotsunami database for New Zealand, J. Nat. Hazards, 54, 193-208 (2008) 